УДК: 616.13/16-073.178:539.3

DOI: $10.15587 / 2313-8416.2014 .33643$

\title{
ВИВЧЕННЯ ПРУЖНО-ЕЛАСТИЧНИХ ВЛАСТИВОСТЕЙ СУДИННОГО РУСЛА
}

\author{
(ㄱ. Л. Є. Лаповець, Ю. І. Онищук, Г. В. Башта, М. О. Войтович, Ю. М. Федевич
}

Дані багатьох епідеміологічних та клінічних спостережень показали, щзо артеріальний тиск змінюються протягом життя людини та в основному визначається периферичним опором, збільшується до досягнення людиною середнього віку, а потім дещзо знижується. Останнім часом спостерігається підвищений інтерес дослідників до вивчення залежності між жорсткістю артерій та кардіоваскулярною захворюваністю, тому вивчення даної теми актуальне

Ключові слова: артеріальний тиск, артеріальна гіпертензія, жорсткість судинної стінки, ивидкість поширення пульсової хвилі

These many epidemiological and clinical observations have shown that blood pressure change during life is mainly determined by peripheral resistance, increased to achieve a middle-aged man, and then slightly decreases. Recently there has been increased interest to researchers in studying the relationship between arterial stiffness and cardiovascular disease. Therefore, the study of the topic is relevant

Keywords: blood pressure, hypertension, vascular wall stiffness, pulse wave velocity distribution

\section{1. Вступ}

Вивчення пружно-еластичних властивостей судинного русла, підвищення жорсткості якого розглядається в якості незалежного чинника ризику розвитку СС3 (серцево-судинних захворювань) $\epsilon$ провідним досліджуваним напрямком патогенезу серцево-судинної патології [1]. Жорсткість артерій $є$ незалежним чинником прогнозу фатальних i нефатальних подій з боку серцево-судинної системи, загальної летальності як у пацієнтів 3 АГ (артеріальною гіпертензією), так і в загальній популяції [2].

\section{2. Постановка проблеми та літературний} огляд

Дослідження H. Debbabi et al. виявили зворотний кореляційний зв'язок між АЖ й щільністю капілярної мережі. Потребує розв'язання низка полемічних питань у вивченні характеру уражень макро- й мікросудин при АГ. Недостатньо вивчено динаміку артеріальної жорсткості у процесі лікування АГ, не доведено реальні переваги антигіпертензивних препаратів, не з'ясовано чи існують незалежні від рівня АТ ефекти гіпотензивних засобів на ШППХ. Немає точних даних про взаємозв'язок мікроциркуляторних порушень 3 ураженням судин великого й середнього калібрів у контексті тактики ведення хворих на АГ [3]. Не розроблено стандартизовані кількісні критерії змін судин мікроциркуляторного русла, немає науково обгрунтованих даних: причиною чи наслідком АГ $є$ розлади мікроциркуляції [4]. Потребує подальшого комплексного вивчення роль мікроциркуляторних розладів у патогенезі ремоделювання магістральних артерій (швидкісні й амплітудні характеристики пульсової хвилі). Викликають дискусію відомості про характер особливостей вікових змін мікроциркуляторного русла у літніх хворих, зокрема при ізольованій систолічній АГ. Зміни стінок великих i середніх артерій відіграють істотну роль у розвитку асоційованих з АГ станів (ішемічна хвороба серця, мультифокальні атеросклеротичні ураження судин, метаболічний синдром) [5-7], що потребує додаткових досліджень їх поєднаної корекції.

3. Артеріальна жорсткість як маркер серцево-судинних захворювань

Велике значення має оцінка загального серцево-судинного ризику, прояви якого залежать не тільки від рівня АТ (артеріального тиску), а також від наявності або відсутності супутніх факторів ризику СС3, уражень органів-мішеней та асоційованих клінічних станів [8-10]. В Європейських рекомендаціях 2007 пропонується враховувати доклінічні зміни в органах-мішенях. Існує велика кількість переконливих доказів того, що значно більша кількість людей, ніж вважалося раніше, мають доклінічне ураження органів - мішеней [11]. Ці ураження можуть передувати стійкому підвищенню АТ і часто не залежать від його рівня. У Російських рекомендаціях $з$ діагностики та лікування АГ 2008 замість терміну «доклінічні зміни в органахмішенях» використовується термін «ураження органів-мішеней» [12-15]. Продемонстровано тісну залежність між частотою розвитку серцево-судинних ускладнень i станом магістральних судин 3 показниками ригідності артерій, у хворих з АГ [16]. Встановлено, що жорсткість артерій - сильніший прогностичний чинник ризику виникнення серцевосудинних ускладнень і смерті у хворих з АГ, ніж класичні фактори [17].

Швидкість пульсової хвилі $\epsilon$ класичним показником розтяжності судинної стінки. У широкомасштабному дослідженні «Complior» (1999) було показано, що швидкості поширення пульсової хвилі (ШППХ) може бути достовірним, об'єктивним методом оцінки розтяжності артерій, і одним 3 незалежних факторів ризику розвитку серцевосудинних ускладнень [18-20]. Існує ряд розрахункових індексів для визначення цього співвідношення: коефіцієнт розтяжності (DC); 
коефіцієнт податливості (СC); содуль жорсткості Петерсона; модуль Юнга (Е); індекс жорсткості $\beta$. Індекс жорсткості $\beta$ - коефіцієнт, який характеризує залежність "напруга - розтягнення" стінки судини, виражений експоненціальною функцією. Визначається за формулою In (PS/PD)/( $\triangle \mathrm{D} / \mathrm{Dmin})$, де PS систолічний $\mathrm{AT}, \mathrm{PD}$ - діастолічний $\mathrm{AT}, \Delta \mathrm{D}$ - різниця найбільшого і найменшого діаметрів судини, Dmin найменший діаметр судини. Індекс жорсткості $\beta \epsilon$ одним $з$ існуючих на сьогоднішній день параметрів, який володіє відносною незалежністю від рівня вимірюваного АТ [21]. За останні десятиліття методика вимірювання ШППХ знову набула великого поширення у зв'язку 3 удосконаленням методів функціональної діагностики і появою нових доказів іiі клінічного значення [22, 23]. ШППХ і параметри, що характеризують жорсткість судин, можуть бути одним із маркерів судинного старіння [24]. Біомеханічні властивості судин, зокрема такий показник пружно - в'язкого стану артерій, як ШППХ, розглядаються в якості одного 3 критеріїв біологічного віку, оскільки вони демонструють тісну залежність 3 хронологічним віком в сукупності 3 іншими критеріями та описують уповільнений або прискорений тип старіння індивідуума [25]. Збільшення ШППХ хоча б на 1 м/с підвищує ризик смерті на $10 \%$, у зв'язку з чим величина ШППХ виступає незалежним предиктором розвитку серцевосудинних захворювань і загальної серцево-судинної смертності. Центральним маркером судинного старіння є найпрогресивніше наростання жорсткості центральних артерій [26].

За даними дослідження відмічено суттєвий вплив підвищеного рівня цукру та діагностованого цукрового діабету (ЦД) на показники пружноеластичних властивостей артерій у пацієнтів після інфаркту міокарда [27]. Підвищення жорсткості артерій у хворих на ЦД розвивається раніше ніж приєднання ангіопатій [28]. Численні дослідження підтверджують дані про підвищення жорсткості артерій у пацієнтів 3 ЦД2, які прогресують при розвитку мікро- і макросудинних ускладнень [29, 30]. Вік $є$ природним фактором жорсткості артерій, він не піддається корекції, однак у пацієнтів з ЦД2 у всіх вікових групах цей показник значимо вищий, ніж в осіб без діабету. Зміни жорсткості артерій виявляються дуже рано, вже на предіабетичній стадії порушень вуглеводного обміну - порушеної толерантності до глюкози і порушеною глікемії натщесерце, а також в осіб 3 метаболічним синдромом [31, 32], підтверджуючи класичну гіпотезу раннього розвитку макросудинних ускладнень до клінічного дебюту ЦД. Ці дані дозволяють розглядати жорсткість артерій в якості одного з ранніх предикторів судинної патології при ЦД, асоційованого 3 ризиком смертності цих пацієнтів.

Результатами останніх досліджень встановлено, що підвищення жорсткості (ригідності) судинної стінки $є$ основним фактором кардіоваскулярних подій $[33,34]$. Їх розвиток реалізується через ендотеліальну дисфункцію та зміну пружно-еластичних властивостей артерій. У цьому сенсі, жорсткість артерій в цілому може бути важливим інтегральним предиктором розвитку кардіоренального континууму [35]. У зв'язку з цим ведеться пошук нових, об'єктивніших маркерів ризику серцево-судинної системи, одним з яких $\epsilon$ жорсткість (ригідність) артерій [36].

У проспективному популяційному дослідженні за участю 1829 данців у віці 40-70 років встановлено значення індексу амбулаторної артеріальної жорсткості для розвитку інсульту [37]. Відомо, що оцінка за Фремінгемського шкалою недостатньо повно описує серцево-судинний ризик. Погіршення високоеластичних властивостей судин може виступати в ролі того упущеного фактора, який здатний забезпечити більш точне прогнозування. Вимірювання жорсткості сонної артерії на додаток до показників товщини комплексу інтима-медіа підвищувало точність прогнозу відносно розвитку інсульту [38]. Піддатливість судинної стінки визначається як зміна обсягу артерії (альтернативаплоща перетину, діаметр), у співвідношенні з даними змінами тиску. Для порівняння еластичних артерій різного калібру розраховують розтяжність відношення податливості до початкового об'єму судини [39]. В даний час стан стінки великих судин, особливо показники судинної жорсткості, розглядають як фактор ризику серцево-судинних ускладнень і мішені органопротекції [40]. Жорсткість судин зростає практично лінійно вже 330 років [41], чим і пояснюється підвищення ризику ускладнень із збільшенням віку, еластичні властивості артерій значною мірою визначаються структурою медії. Лише в останні роки стало очевидним, незважаючи на наявність великої кількості даних, отриманих ще на початку 20 століття, що форма пульсової хвилі має істотне значення 3 точки зору характеристик патології та віддаленого прогнозу [42].

\section{4. Висновки}

У зв'язку 3 цим особливо привабливим став новий метод оцінки артеріальної ригідності неінвазивна артеріографія. Відзначена повна ідентичність аортальних пульсовиххвиль, зареєстрованих інвазивним і неінвазивним способами [43]. Визнання останнім часом артеріальної ригідності одним 3 основних критеріїв кардіоваскулярного ризику [44, 45], можливість неінвазивної оцінки основних параметрів жорсткості судинної стінки. Отже визначення ригідності артерій, а також інших показників артеріальної жорсткості $€$ необхідними для правильної та своєчасної діагностики та лікування серцево-судинної патології .

\section{Література}

1. Лукьянов, М. М. Жесткость артериальной стенки как фактор сердечно-сосудистого риска [Текст] / М. М. Лукьянов, С. А. Бойцов // Сердце. - 2010. № 3 (53). - C.156-160.

2. Дзяк, Г. В. Динаміка показників жорсткості артеріальної стінки на тлі комбінованої антигіпертензивної терапії [Текст] / Г. В. Дзяк, Т. В. Колесник, Е. Л. Колесник // Укр. мед. часопис. - 2011. - № 5 (85). - С. 57-59. 
3. Renna, N. F. Pathophysiology of vascular remodeling in hypertension [Text] / N. F. Renna, N. Heras, R. M. Miatello // International Journal of Hypertension. 2013. - Vol. 2013. - P. 1-7. doi: 10.1155/2013/808353

4. Nichols, W. McDonald's Blood flow in arteries. Theoretical,experimental and clinical principles [Text] / W. Nichols, M. O'Rourke, C.Vlachopoulos. - Edn.6. - CRC Press: Hodder Arnold Publication, 2011. - 768 p. doi: $10.1201 / \mathrm{b} 13568$

5. Cheng, C. Capillary rarefi cation in treated and untreated hypertensive subjects [Text] / C. Cheng, C. Daskalakis, B. Falkner // Therapeutic Advances in Cardiovascular Disease. - 2008. - Vol. 2, Issue 2. - P. 79-88. doi: $10.1177 / 1753944708089696$

6. Feihl, F. The macrocirculation and microcirculation of hypertension [Text] / F. Feihl, L. Liaudet, B. Waeber // Current Hypertension Reports. - 2009. - Vol. 11, Issue 3. P. 182-189. doi: 10.1007/s11906-009-0033-6

7. Mathiassen, O. N. Small artery structure is an independent predictor of cardiovascular events in essential hypertension [Text] / O. N. Mathiassen, M. J.Mulvany, K. L. Christensen et al. // Journal of Hypertension. - 2007. Vol. 25, Issue 5. - P.1021-1026.

\section{doi: 10.1097/hjh.0b013e32805bf8ed}

8. Сторожаков, Г. И. Оценка эластических свойств артериальной стенки у больных артериальной гипертонией молодого возраста [Текст] / Г. И. Сторожаков, Г. С. Верещагина, Ю. Б. Червякова и др. // Артериальная гипертензия. - 2005. - № 1. - С. 33-36.

9. Dijk, J. M. Carotid stiffness and the risk of new vascular events in patients with manifest cardiovascular disease. The SMART study [Text] / J. M. Dijk, A Algra, Y van der Graaf et al. // European Heart Journal. - 2005. - Vol. 26, Issue 12. - P. 1213-1220. doi: 10.1093/eurheartj/ehi254

10. Schillaci, M. P. G. Low-grade systemic inflammation impairs arterial stiffness in newly diagnosed hypercholesterolaemia [Text] / M. Pirro G. Schillaci, R. Paltriccia et al. // European Journal of Clinical Investigation. 2004. - Vol. 34, Issue 5. - P. 335-341. doi: 10.1111/j.13652362.2004.01345.x

11. Mancia, G. Guidelines for the Management of Arterial Hypertension: The Task Force for the Management of Arterial Hypertension of the European Society of Hypertension (ESH) and of the European Society of Cardiology (ESC) [Text] / G. Mancia, G. De Backer, A. Dominiczak et al. // Journal of Hypertension. - 2007. - Vol. 25, Issue 6. - P. 1105-1187.

12. Рогоза, А. Н. Неинвазивные методы определения ригидности магистральных артерий [Текст] / А. Н. Рогоза // Функціональна діагностика. - 2007. - № 3. C. $17-32$.

13. Lim, H. E. Aortic pulse wave velocity as an independent marker of coronary artery disease [Text] / H. E. Lim, C. G. Park, S. H. Shin et al. // Blood Press. - 2004. Vol. 13, Issue 6. - $\quad$ P. 369-375. doi: $10.1080 / 08037050410004800$

14. Nagano, M. Association between serum C-reactive protein levels and pulse wave velocity: a population-based cross-sectional study in a general population [Text] / M. Nagano, M. Nakamura, K. Sato et al. // Atherosclerosis. 2005. - Vol. 180, Issue 1. - P. 189-195. doi: 10.1016/j.atherosclerosis.2004.11.019

15. Eren, M. Relation between aortic stiffness and left ventricular diastolic function in patients with hypertension, diabetes, or both [Text] / M. Eren, S Gorgulu, N Uslu et al. // Heart. - 2004. - Vol. 90, Issue 1. - P. 37-43. doi: 10.1136/heart.90.1.37

16. Радченко, А. Д. Клиническое исследование ЭЛИЗА. Результаты 6-месячного наблюдения [Текст] /
А. Д. Радченко, К. В. Михеева, Ю. Н. Сиренко и др. Донецк: Издательский дом 《Заславский》, 2011. - 64 с.

17. Целуйко, В. И. Факторы, ассоциированные с показателями центрального аортального давления у больных с артериальной гипертензией [Текст] / В. И. Целуйко, Т. Р. Брегвадзе, Н. Е. Мищук // Украинский кардиологический журнал. - 2012. - № 10. - С. 58-66.

18. Андреевская, М. В. Воспроизводимость результатов определения ригидности аорты ультразвуковыми методами [Текст] / М. В. Андреевская, М. А. Саидова, А. Н. Рогоза // Тезисы 5-го Съезда Российской ассоциации специалистов ультразвуковой диагностики в медицине. М., 2007. - С. 78.

19. Laurent, S. Expert consensus document on arterial stiffness: methodological issues and clinical applications [Text] / S. Laurent, J. Cockcroft, L. Van Bortel et al. // European Heart Journal. - 2006. - Vol. 27, Issue 21. - P. 2588-2605. doi: 10.1093/eurheartj/ehl254

20. Pietri, P. Relationship between low-grade inflammation and arterial stiffness in patients with essential hypertension [Text] / P. Pietri, G. Vyssoulis, C. Vlachopoulos et al. // Journal of Hypertension. - 2006. - Vol. 24, Issue 11. P. 2231-2238. doi: 10.1097/01.hjh.0000249701.49854.21

21. Jiang, B. Measurement of pulse wave velocity using pulse wave Doppler ultrasound: comparison with arterial tonometry [Text] / B. Jiang, B. Liu, K. L. McNeill et al. // Ultrasound in Medicine \& Biology. - 2008. - Vol. 34, Issue 3. - P. 509-512. doi: 10.1016/j.ultrasmedbio.2007.09.008

22. Илюхин, О. В. Скорость распространения пульсовой волны и эластические свойства магистральных артерий: факторы, влияющие на их механические свойства, возможности диагностической оценки [Текст] / О. В. Илюхин, Ю. М. Лопатин // Вестник ВолГМУ. - 2006. - № 1. C. 3-8.

23. Кочкина, М. С. Измерение жесткости артерий и ее клиническое значение [Текст] / М. С. Кочкина, Д. А. Затейщиков, Б. А. Сидоренко // Кардиология. - 2005. - № 1. C. $64-72$.

24. Корнева, В. А. Артериальная жесткость - новый маркерсердечно-сосудистых заболеваний [Текст] / В. А. Корнева, В. В. Отмахов, М. А. Дружилов и др. // СardioСоматика. - 2012. - № 1. - С. 34-37.

25. Ахаладзе, Н. Г. Биологический возраст человека. Оценка темпа старения, здоровья и жизнеспособности [Текст] / Н. Г. Ахаладзе, Л. М. Ена. Киев-Ирпень: Перун, 2009. - 256 с.

26. Jani, B. Ageing and vascular ageing [Text] / B. Jani, C. Rajkumar // Postgraduate Medical Journal. - 2006. Vol. 82, Issue 967. - P. 357-362. doi: 10.1136/pgmj.2005.036053

27. Сіренко, Ю. М. Пружно-еластичні властивості артерій: визначення, методи дослідження, значення у практиці лікаря-кардіолога [Текст] / Ю. М. Сіренко, Г. Д. Радченко // Укр. кардіол. журн. - 2009. - № 4(6). С. $52-67$.

28. Gomez-Marcos, M. A. Relationship between intima-media thickness of the common carotid artery and arterial stiffness in subjects with and without type 2 diabetes: a case-series report [Text] / M. A. Gomez-Marcos, J. I. RecioRodriguez, M. C. Patino-Alonso et al. // Cardiovasc Diabetol. 2011. - Vol. 10, Issue 3. - P. 1-8. doi: 10.1186/1475-2840-10-3

29. Hermans, M. M. Estimated glomerular filtration rate and urinary albumin excretion are independently associated with greater arterial stiffness: the Hoorn Study [Text] / M. M. Hermans, R. Henry, J. M. Dekker et al. // Journal of the American Society of Nephrology. - 2007. - Vol. 18, Issue 6. P. 1942-1952. doi: 10.1681/asn.2006111217

30. Smith, A. Aortic pulse wave velocity and albuminuria in patients with type 2 diabetes [Text] / A. Smith, 
J. Karalliedde, L. De Angelis et al. // Journal of the American Society of Nephrology. - 2005. - Vol. 16, Issue 4. P. 1069-1075. doi: 10.1681/asn.2004090769

31. Ahluwalia, N. Metabolic syndrome is associated with markers of subclinical atherosclerosis in a French population-based sample [Text] / N. Ahluwalia, L. Drouet, J. B. Ruidavets et al. // Atherosclerosis. - 2006. - Vol. 186, Issue 2. - P. 345-353.

doi: 10.1016/j.atherosclerosis.2005.07.021

32. Safar, M. E. Metabolic syndrome and age-related progression of aortic stiffness [Text] / M. E. Safar, F. Thomas, J. Blacher et al. // Journal of the American College of Cardiology. - 2006. - Vol. 47, Issue 1. - P. 72-75. doi: 10.1016/j.jacc.2005.08.052

33. Світлана, I. Стан судинного артеріального русла у хворих після інфаркту міокарда на амбулаторному етапі реабілітації [Текст] / I. Світлана, Я. Андрій // Молода спортивна наука України. - 2012. - Т. 3. - С. 100-104.

34. Nilsson, P. M. The early life origins of vascular ageing and cardiovascular risk: the EVA syndrome [Text] / P. M. Nilsson, S. Laurent, E. Lurbe // Journal of Hypertension. - 2008. - Vol. 26, Issue 6. - P. 1049-1057.

doi: 10.1097/hjh.0b013e3282f82c3e

35. Новые возможности оценки артериальной ригидности - раннего маркера развития сердечнососудистых заболеваний [Текст] : матер. симпозиума / А. И. Мартынов (ред.) // Рус. врач, Москва, 2007. - 48 с.

36. Радченко, Г. Д. Пульсовий артеріальній тиск та індекс жорсткості аорти: вплив на прогноз у пацієнтів 3 артеріальною гіпертензією, які пройшли Лікування у спеціалізованому відділенні [Текст] / Г. Д. Радченко, Ю. М. Сіренко // Артеріальна гіпертензія. - 2009. № 2 (4). - C. 37-43.

37. Бойцов, С. А. Проблемы выявления лиц с высоким сердечно-сосудистым риском и возможные пути их решения (ч. 1) [Текст] / С. А. Бойцов, Ю. А. Карпов, В. В. Кухарчук и др. // Атеросклероз и дислипидемии. 2010. - № 1. - C. 8-14.

38. Hansen, T. W. Ambulatory arterial stiffness index predict stroke in a general population [Text] / T. W. Hansen, J. A. Staessen, C. Torp-Redersen et al. // Journal of Hypertension. - 2006. - Vol. 24, Issue 11. - P. 2347-2352. doi: 10.1097/01.hjh.0000249703.57478.78

39. Harloff, A. Combined measurement of carotid stiffness and intima-media thickness improves prediction of complex aortic plague in patients with ischemic stroke [Text] / A. Harloff, C. Strecker, M. Reinhard et al. // Stroke. - 2006. Vol. 37, Issue 11. - P. 3708-3713.

doi: 10.1161/01.str.0000244763.19013.dc

40. Кочкина, М. С. Измерение жесткости артерий и ее клиническое значение [Текст] / М. С. Кочкина, Д. А. Затейщиков, Б. А. Сидоренко // Кардиология. - 2005. - № 1. C. $63-71$.

41. Mancia, G. 2007 Guidelines for the Management of Arterial Hypertension. The Task Force for the Management of Arterial Hypertension of the European Society of Hypertension (ESH) and of the European Society of Cardiology (ESC) [Text] / G. Mancia, G. De Backer, A. Dominiczak, R. Cifkova, R. Fagard, G. Germano et. al. // Journal of Hypertension. 2007. - Vol. 25, Issue 6. - P. 1105-1187.

doi: 10.1097/hjh.0b013e3281fc975a

42. Heanson, T. Prognostic value of aortic pulse wave velocity as index of arterial stiffness in general population [Text] / T. Heanson, J. Staessen, T. Pedersen et al. // Circulation. - 2006. - Vol. 113, Issue 5. - P. 664-670. doi: 10.1161/circulationaha.105.579342

43. Laurent, S. Central aortic blood pressure [Text] / S. Laurent, J. Cocroft. - Elsevier, 2008. -65 p.
44. Safar, M. E. Pulse pressure, arterial stiffness and wave refl ections (augmentation index) as cardiovascular risk factors in hypertension [Text] / M. E. Safar // Therapeutic Advances in Cardiovascular Disease. - 2008. - Vol. 2, Issue 1. - P. 13-24. doi: 10.1177/1753944707086652

45. Baulmann, J. A new oscillometric method for assessment of arterial stiffness: comparison with tonometric and piezo-electronic methods [Text] / J. Baulmann, U. Schillings, S. Rickert et al. // Journal of Hypertension. 2008. - Vol. 26, Issue 3. - P. 523-528. doi: 10.1097/hjh.0b013e3282f314f7

\section{References}

1. Luk'yanov, M. M., Boytsov, S. A. (2010). Zhestkost' arteryal'noy stenky kak faktor serdechno-sosudystoho ryska. Serdtse, 3 (53), 156-160.

2. Dzyak, H. V., Kolesnyk, T. V., Kolesnyk, E. L. (2011). Dynamika pokaznykiv zhorstkosti arterial'noyi stinky na tli kombinovanoyi antyhipertenzyvnoyi terapiyi. Ukr. med. chasopys, 5 (85), 57-59.

3. Renna, N. F., Heras, N., Miatello, R. M. (2013). Pathophysiology of vascular remodeling in hypertension. International Journal of Hypertension, 2013, 1-7. doi: $10.1155 / 2013 / 808353$

4. Nichols, W., Rourke, M. O., Vlachopoulos, C. (2011). McDonald"s Blood flow in arteries. Theoretical,experimental and clinical principles. Edn.6. CRC Press: Hodder Arnold Publicationyu, 768. doi: 10.1201/b13568

5. Cheng, C., Daskalakis, C., Falkner, B. (2008). Capillary rarefi cation in treated and untreated hypertensive subjects. Therapeutic Advances in Cardiovascular Disease, 2 (2), 79-88. doi: 10.1177/1753944708089696

6. Feihl, F., Liaudet, L., Waeber, B. (2009). The macrocirculation and microcirculation of hypertension. Current Hypertension Reports, 11 (3), 182-189. doi: 10.1007/s11906009-0033-6

7. Mathiassen, O. N., Mulvany, M. J., Christensen, K. L. et al. (2007). Small artery structure is an independent predictor of cardiovascular events in essential hypertension. Journal of Hypertension, 25 (5), 1021-1026. doi: 10.1097/hjh.0b013e32805bf8ed

8. Storozhakov, H. Y., Vereshchahyna, H. S., Chervyakova, Yu. B. et. al. (2005). Otsenka elastycheskykh svoystv arteryal'noy stenky u bol'nikh arteryal'noy hypertonyey molodoho vozrasta. Arteryal'naya hypertenzyya, 1, 33-36.

9. Dijk, J. M., Algra, A., van der Graaf, Y. et al. (2005). Carotid stiffness and the risk of new vascular events in patients with manifest cardiovascular disease. The SMART study. European Heart Journal, 26 (12), 1213-1220. doi: 10.1093/eurheartj/ehi254

10. Schillaci, M. P. G., Paltriccia, R. et al. (2004). Low-grade systemic inflammation impairs arterial stiffness in newly diagnosed hypercholesterolaemia. European Journal of Clinical Investigation, 34 (5), 335-341. doi: 10.1111/j.13652362.2004.01345.x

11. Mancia, G., De Backer, G., Dominiczak, A. et al. (2007). Guidelines for the Management of Arterial Hypertension: The Task Force for the Management of Arterial Hypertension of the European Society of Hypertension (ESH) and of the European Society of Cardiology (ESC). Journal of Hypertension, 25 (6), 1105-1187.

12. Rohoza, A. N. (2007). Neynvazyvnie metodi opredelenyya ryhydnosty mahystral'nikh arteryy. Funktsional'na diahnostyka, 3, 17-32.

13. Lim, H. E., Park, C. G., Shin, S. H. et al. (2004). Aortic pulse wave velocity as an independent marker of coronary artery disease. Blood Press, 13 (6), 369-375. doi: $10.1080 / 08037050410004800$ 
14. Nagano, M., Nakamura, M., Sato, K. et al. (2005). Association between serum C-reactive protein levels and pulse wave velocity: a population-based cross-sectional study in a general population. Atherosclerosis, 180 (1), 189-195.

doi: 10.1016/j.atherosclerosis.2004.11.019

15. Eren, M., Gorgulu, S., Uslu, N. et al. (2004). Relation between aortic stiffness and left ventricular diastolic function in patients with hypertension, diabetes, or both. Heart, 90 (1), 37-43. doi: 10.1136/heart.90.1.37

16. Radchenko, A. D., Mykheeva, K. V., Syrenko, Yu. N. et. al. (2011). Klynycheskoe yssledovanye ЭLYZA. Rezul'tati 6-mesyachnoho nablyudenyya. Donetsk: Yzdatel'skyy dom 《Zaslavskyy», 64.17. Tseluyko, V. Y., Brehvadze, T. R., Myshchuk, N. E. (2012). Faktori, assotsyyrovannie s pokazatelyamy tsentral'noho aortal'noho davlenyya u bol'nikh s arteryal'noy hypertenzyey. Ukr. kard. zh., 10, 58-66.

18. Andreevskaya, M. V., Saydova, M. A., Rohoza, A. N. (2007). Vosproyzvodymost' rezul'tatov opredelenyya ryhydnosty aorti ul'trazvukovimy metodamy. Tezysi 5-ho Sezda Rossyyskoy assotsyatsyy spetsyalystov ul'trazvukovoy dyahnostyky v medytsyne. Moscow, 78.

19. Laurent, S., Cockcroft, J., Van Bortel, L. et al. (2006). Expert consensus document on arterial stiffness: methodological issues and clinical applications. European Heart Journal, 27 (21), 2588-2605. doi: 10.1093/eurheartj/ehl254

20. Pietri, P., Vyssoulis, G., Vlachopoulos, C. et al. (2006). Relationship between low-grade inflammation and arterial stiffness in patients with essential hypertension. Journal of Hypertension, $24 \quad$ (11), 2231-2238. doi: 10.1097/01.hjh.0000249701.49854.21

21. Jiang, V., Liu, B., McNeill, K. L. et al. (2008). Measurement of pulse wave velocity using pulse wave Doppler ultrasound: comparison with arterial tonometry. Ultrasound in Medicine \& Biology, 34 (3), 509-512.

doi: 10.1016/j.ultrasmedbio.2007.09.008

22. Ylyukhyn, O. V., Lopatyn, Yu. M. (2006). Skorost' rasprostranenyya pul'sovoy volnы у эlastycheskye svoystva mahystral'nikh arteryy: faktori, vlyyayushchye na ykh mekhanycheskye svoystva, vozmozhnosty dyahnostycheskoy otsenky. Vestnyk VolHMU, 1, 3-8.

23. Kochkyna, M. S., Zateyshchykov, D. A., Sydorenko, B. A. (2005). Yzmerenye zhestkosty arteryy y ee klynycheskoe znachenye. Kardyolohyya, 1, 64-72.

24. Korneva, V. A., Otmakhov, V. V., Druzhylov, M. A. et. al. (2012). Arteryal'naya zhestkost' - noviy markerserdechno-sosudystikh zabolevanyy. CardioSomatyka, $1,34-37$.

25. Akhaladze, N. H., Ena, L. M. (2009). Byolohycheskyy vozrast cheloveka. Otsenka tempa starenyya, zdorov'ya y zhyznesposobnosty. Kyev-Yrpen': Perun, 256.

26. Jani, B., Rajkumar, C. (2006). Ageing and vascular ageing. Postgraduate Medical Journal, 82 (967), 357-362.

doi: 10.1136/pgmj.2005.036053

27. Sirenko, Yu. M., Radchenko, H. D. (2009). Pruzhno-elastychni vlastyvosti arteriy: vyznachennya, metody doslidzhennya, znachennya u praktytsi likarya-kardioloha. Ukr. kardiol. zhurn., 4(6), 52-67.

28. Gomez-Marcos, M. A., Recio-Rodriguez, J. I., Patino-Alonso, M. C. et al. (2011). Relationship between intima-media thickness of the common carotid artery and arterial stiffness in subjects with and without type 2 diabetes: a case-series report. Cardiovasc Diabetol, 10(3), 1-8.

doi: 10.1186/1475-2840-10-3

29. Hermans, M. M., Henry, R., Dekker, J. M. et al. (2007). Estimated glomerular filtration rate and urinary albumin excretion are independently associated with greater arterial stiffness: the Hoorn Study. Journal of the American Society of Nephrology, 18 (6), 1942-1952. doi: 10.1681/asn.2006111217
30. Smith, A., Karalliedde, J., De Angelis, L. et al. (2005). Aortic pulse wave velocity and albuminuria in patients with type 2 diabetes. Journal of the American Society of Nephrology, 16 (4), 1069-1075. doi: 10.1681/asn.2004090769

31. Ahluwalia, N., Drouet, L., Ruidavets, J. B. et al (2006). Metabolic syndrome is associated with markers of subclinical atherosclerosis in a French population-based sample. Atherosclerosis, 186, 345-353.

doi: 10.1016/j.atherosclerosis.2005.07.021

32. Safar, M. E., Thomas, F., Blacher, J. et al. (2006). Metabolic syndrome and age-related progression of aortic stiffness. Journal of the American College of Cardiology, 47 (1), 72-75. doi: 10.1016/j.jacc.2005.08.052

33. Svitlana, I., Andriy, Ya. (2012). Ctan sudynnoho arterial'noho rusla $\mathrm{u}$ khvorykh pislya infarktu miokarda na ambulatornomu etapi reabilitatsiyi. Moloda sportyvna nauka Ukrayiny, 3, 100-104.

34. Nilsson, P. M., Laurent, S., Lurbe, E. (2008). The early life origins of vascular ageing and cardiovascular risk: the EVA syndrome. Journal of Hypertension, 26 (6), 1049-1057. doi: 10.1097/hjh.0b013e3282f82c3e

35. Martinov, A. Y. (2007). Novye vozmozhnosty otsenky arteryal'noy ryhydnosty - ranneho markera razvytyya serdechno-sosudystikh zabolevanyy. Materyali sympozyuma. Rus. vrach, Moscow, 48.

36. Radchenko, H. D., Sirenko, Yu. M. (2009). Pul'sovyy arterial'niy tysk ta indeks zhorstkosti aorty: vplyv na prohnoz $\mathrm{u}$ patsiyentiv $\mathrm{z}$ arterial'noyu hipertenziyeyu, yaki proyshly Likuvannya u spetsializovanomu viddilenni. Arterial'na hipertenziya, 2 (4), 37-43.

37. Boytsov, S. A., Karpov, Yu. A., Kukharchuk, V. V. et. al. (2010). Problemi viyavlenyya lyts s visokym serdechnososudystim ryskom y vozmozhnie puty ykh reshenyya (Part 1). Ateroskleroz y dyslypydemyy, 1, 8-14.

38. Hansen, T. W., Staessen, J. A., Torp-Redersen, C. et. al. (2006). Ambulatory arterial stiffness index predict stroke in a general population. Journal of Hypertension, 24 (11), 2347-2352. doi: 10.1097/01.hjh.0000249703.57478.78

39. Harloff, A., Strecker, C., Reinhard, M. et al. (2006). Combined measurement of carotid stiffness and intima-media thickness improves prediction of complex aortic plague in patients with ischemic stroke. Stroke, 37 (11), 3708-3713. doi: 10.1161/01.str.0000244763.19013.dc

40. Kochkyna, M. S., Zateyshchykov, D. A., Sydorenko, B. A. (2005). Yzmerenye zhestkosty arteryy y ee klynycheskoe znachenye. Kardyolohyya, 1, 63-71.

41. Mancia, G., De Backer, G., Dominiczak, A., Cifkova, R., Fagard, R., Germano, G. (2007). 2007 Guidelines for the Management of Arterial Hypertension. The Task Force for the Management of Arterial Hypertension of the European Society of Hypertension (ESH) and of the European Society of Cardiology (ESC) // J. Hypertens, 25 (6), 1105-1187. doi: 10.1097/hjh.0b013e3281fc975a

42. Heanson, T., Staessen, J., Pedersen, T. et al. (2006). Prognostic value of aortic pulse wave velocity as index of arterial stiffness in general population. Circulation, 113 (5), 664-670. doi: 10.1161/circulationaha.105.579342

43. Laurent, S., Cocroft, J. (2008). Central aortic blood pressure. Elsevier, 65.

44. Safar, M. E. (2008). Pulse pressure, arterial stiffness and wave refl ections (augmentation index) as cardiovascular risk factors in hypertension. Therapeutic Advances in Cardiovascular Disease, 2 (1), 13-24. doi: $10.1177 / 1753944707086652$

45. Baulmann, J., Schillings, U., Rickert, S. et al. (2008). A new oscillometric method for assessment of arterial stiffness: comparison with tonometric and piezo-electronic methods. Journal of Hypertension, 26 (3), 523-528. doi: 10.1097/hjh.0b013e3282f314f7 
Рекомендовано до публікаиії д-р мед. наук Лаповецьь Л. С. Дата надходження рукопису 30.11.2014

Лаповець Любов Свгенівна, кандидат медичних наук, професор, кафедра клінічної лабораторної діагностики факультету післядипломної освіти, Львівський національний медичний університет ім. Данила Галицького, вул. Миколайчука 9, м. Львів, Україна, 79000

E-mail: lapovets@ukr.net

Башта Галина Володимирівна, кандидат медичних наук, доцент, кафедра сімейної медицини факультету післядипломної освіти, Львівський національний медичний університет ім. Данила Галицького, вул. Миколайчука 9, м. Львів, Україна, 79000

E-mail: baschta@ukr.net

Онищук Юлія Іванівна, кандидат медичних наук, Кафедра сімейної медицини факультету післядипломної освіти. Львівський національний медичний університет ім. Данила Галицького, вул. Миколайчука 9, м. Львів, Україна, 79000

E-mail: ferocina21@rambler.ru

Войтович Мар'яна Олександрівна, ординатор, кафедра сімейної медицини факультету післядипломної освіти, Львівський національний медичний університет ім. Данила Галицького, вул. Миколайчука 9 , м. Львів, Україна, 79000

E-mail: 23011981maryana@gmail.com

Федевич Юрій Миронович, кандидат медичних наук, доцент, кафедра біологічної хімії, Львівський національний медичний університет ім. Данила Галицького, вул. Миколайчука 9, м. Львів, Україна, 79000

\section{UDC 616-05}

DOI: $10.15587 / 2313-8416.2014 .34599$

\section{PATIENT ELECTRONIC MEDICAL RECORD - THE IMPORTANCE OF PROPER IMPLEMENTATION ASSESSMENT}

\section{(C) Maria Karlińska}

Digital technologies offer the potential to transform health care. Electronic Medical Record (EMR) is used to make paperless computerized patient data in order to increase efficiency of hospital systems and reduce chances of human errors. Its level of implementation is usually assessed using an EMR Adoption Model (EMRAM)

Keywords: Electronic Medical Record, digital healthcare, hospital information systems, medical informatics, eHealth

Цифрові технології пропонують потенщіал для перетворення охорони здоров'я. Електронна медична карта (EMR) використовується для створення безпаперових комп'ютеризованих даних пачієнта $з$ метою підвищення ефективності лікарняних систем і зменшити шанси людських помилок. Ї̈̈ рівень реалізаиії, як правило, оцінюється за допомогою моделі адаптації ЕMR (EMRAM)

Ключові слова: електронна медична карта, иифрова охорона здоров'я, інформаційні системи лікарень, медична інформатика, електронна охорона здоров'я

\section{Introduction}

Since the 1990 we have witnessed a substantial development in the field of telemedicine and eHealth. Technologies that support (i) storing, managing, and transmission of data; (ii) clinical decision making; and (iii) health services from a distance have become an important part of many health care systems, especially in Western societies.
Electronic medical record (EMR) or electronic health record (EHR) are among the most important components of eHealth. Although both terms are often used interchangeably, on legal grounds they have a different meaning. EMRs are defined as patient treatment records, including a patient's background information and history of patient care, that maintained within a hospital or an outpatient clinic. On the other hand, EHRs are all patient health records, include clinical data and 